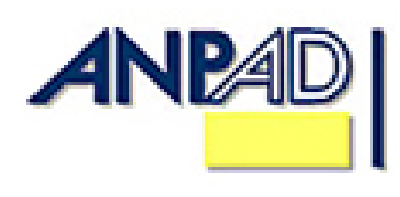

Available online at http://www.anpad.org.br/bar

BAR, Curitiba, v. 8, n. 3, art. 6 , pp. 329-350, July/Sept. 2011

\title{
Performance Effects of Stakeholder Interaction in Emerging Economies: Evidence from Brazil
}

Rodrigo Bandeira-de-Mello* E-mail address: rodrigo.bandeira.demello@fgv.br Fundação Getúlio Vargas - FGV/EAESP

São Paulo, SP, Brazil.

Rosilene Marcon

E-mail address: rmarcon@univali.br Universidade do Vale do Itajaí - PPGA/UNIVALI Biguaçu, SC, Brazil.

Anete Alberton

E-mail address: anete@univali.br Universidade do Vale do Itajaí - PPGA/UNIVALI

Biguaçu, SC, Brazil.

* Corresponding author: Rodrigo Bandeira-de-Mello

EAESP/ADM, Rua Itapeva, 474, $11^{\circ}$ andar, Bela Vista, São Paulo, SP, 01332-000, Brazil.

Copyright (C) 2011 Brazilian Administration Review. All rights reserved, including rights for translation. Parts of this work may be quoted without prior knowledge on the condition that the source is identified. 


\begin{abstract}
Firm survival in emerging economies is often related to having access to valuable resources that are in stakeholders' hands. However, the literature on strategy in emerging economies provides scant information on the efficiency of acquiring stakeholder resources and its effect on firm performance. We investigated the stakeholder interaction effects on performance of domestic firms competing in an emerging market (Wright, Filatotchev, Hoskisson, \& Peng, 2005) from a contractual perspective (Williamson, 1985). We argue that interacting stakeholders in a contractual set yield synergistic governance structures that allow firms more efficient access to external resources. Using a sample of 267 firms in Brazil (secondary data), we explored different patterns in stakeholder contracting with community, government, top management, and employees. A three-stage analysis process was devised: cluster analysis, general linear model estimation and verification tests. Results suggest that stakeholder interaction has a positive impact on firm performance. The conjoint effect of government and community contracts was found to yield superior firm performance as they provide a basic structure for contracting with other interacting stakeholders.
\end{abstract}

Key words: emerging economies; firm performance; relational contracts; stakeholder management. 


\section{Introduction}

Mainstream research in Strategy has focused primarily on industry and firm effects as determinants of firm performance (e.g. McGahan \& Porter, 1997; McGahan \& Victer, 2010; Rumelt, 1991, e.g. for Brazil, Bandeira-de-Mello \& Marcon, 2006; Brito \& Vasconcelos, 2004, 2005), disregarding institutional differences (Peng, 2002). Nonetheless, some studies in this line of research have reported the importance of national institutional differences. For example, Carvalho, Bandeirade-Mello, Vianna and Marcon (2009) found relevant stable and transient country effects in a Latin American sample of firms. Goldszmidt, Brito and Vasconcelos (2007) found that country, industry and country-industry interaction effects had approximately the same relative importance in performance variance decomposition; and altogether, these effects were nearly as important as the firm effect. These country differences arise from differences in national formal and informal institutional arrangements, which affect the way business is done, as well as the resulting performance distribution (Griffiths \& Zammuto, 2005).

Indeed, emerging economies' idiosyncrasies have urged mainstream strategy theories to better specification and towards the consideration of multiple theoretical perspectives (Hoskisson, Eden, Lau, \& Wright, 2000; Wright, Filatotchev, Hoskisson, \& Peng, 2005). While emerging market economies are characterized by the rapid pace of their economic development, by policies towards economic liberalization, and by the adoption of a free-market system (Hoskisson et al., 2000), they also show remarkable differences from the taken-for-granted assumptions of mainstream research in Strategy. Weak formal institutions, economic and political instability, corruption and bribery, high degrees of environmental uncertainty, underdeveloped financial markets, and strong emphasis on informal organizations defy theorizing within the context of emerging economies (Farashahi \& Molz, 2004).

Firm organization and strategy in emerging economies seem to rely heavily on distinctive relationships with external actors. One may cite the studies on diversified business groups as a response to cope with market failures in high transaction cost environments (Guillén, 2000; Khanna \& Palepu, 2000), and the role of non-market capabilities to grant access to scarce, valuable country resources in support of unrelated diversification (Wan, 2005). The pervasive influence of the government in business and the necessity to establish connections with the powerful shape-organizing activities in China and transition economies (Pearce, 2001), help to improve overall firm performance (Peng \& Luo, 2000), can serve as first mover advantages for companies entering emerging markets (Rahman \& Bhattacharyya, 2003), and are part of the multinational companies' lives (Holtbrügge, Berg, \& Puck, 2007).

Despite the fact that external actors are important in emerging market contexts, the literature on strategy is relatively silent in analyzing how these actors interact and to what extent this interaction affects firm performance (Luk, Yau, Tse, Sin, \& Chow, 2005). Theoretical propositions about firm relationships with multiple stakeholders (Neville \& Menguc, 2006; Pajumen, 2006) and methodologies for helping managers make decisions involving multiple conflicting stakeholder claims (Winn \& Keller, 2001) have been proposed. Only recently, stakeholder theory has begun to reemerge in the strategy and performance discussion (Choi \& Wang, 2009; Harrison, Bosse, \& Phillips, 2010; Luque, Washburn, Waldman, \& House, 2008). However, which firm-stakeholder interactions managers should decide to nurture in order to positively affect firm performance in emerging markets remains a question to be better investigated.

The present research fills this gap. The purpose of this paper is to advance the research on domestic firms competing within emerging economies (Wright et al., 2005) by offering a new approach to understand and measure the performance effects of firm relationships with external actors. Our approach uses a contractual metaphor to understand firm-stakeholder relationships (Cornell \& Shapiro, 1987; Jones, 1995; Williamson, 1985) in weak environments. We suggest that superior firms' performance is associated with efficiently 'contracting' multiple interacting stakeholders. Efficiency 
would come not only through reducing costs in a single stakeholder relationship, but from economies of scope among contracts with interacting stakeholders. Interaction makes it possible to economize on stakeholder relationships and curb opportunism even in the weak environments of emerging economies.

We explore the performance effects of stakeholder contracting for the case of Brazil, an important emerging economy (Hoskisson et al., 2000). While Brazilian firms may benefit from an increasing level of available economic factors, they face a high transaction cost environment due to political instability and bureaucratic inefficiency (Wan, 2005). We believe that by developing relationships with key stakeholders, transaction and resource costs are reduced to the extent to which stakeholders in the firm contractual set interact with each other. We verify our stakeholder interaction argument in the Brazilian context. Contracting patterns are identified and described. Performance effects of each contracting pattern are measured and a fine-grained analysis of the best contract combination is provided and checked, allowing for further theory development.

This paper extends existing literature in three ways. First, we took on the suggestion of Wright, Filatotchev, Hoskisson and Peng (2005) of using multiple theoretical streams - Stakeholder Theory and Transaction Cost Economics - to give conceptual support and to guide our exploratory intent. Second, our stakeholder-based approach does not constrain the filling of institutional voids to business group or network memberships (Khanna \& Palepu, 2000). We suggest that independent firms may also develop their own mechanisms to reduce transaction costs, and access key resources in weak institutional markets. Third, we offer a novel way to model, theoretically and empirically, the stakeholder effects on firm performance, overcoming methodological difficulties of data collection and reliability, common to research in these settings (Hoskisson et al., 2000). We believe that this exploratory investigation in the Brazilian context offers fresh insights into strategy research and the practice of domestic firms in emerging economies.

\section{A Contract Metaphor for Managing Stakeholder Interactions}

The use of contracts to understand social and economic relations has received influences from different theories in Sociology, Economics, Law, and Organization Theory (Heugens, Oosterhout, \& Vromen, 2004; Williamson, 1985). In the field of Business and Society, contracts are also used to explain firms' relationships with their stakeholders (Donaldson \& Dunfee, 1999; Freeman \& Evan, 1990; Friedman \& Miles, 2002; Hill \& Jones, 1992; Jones, 1995; Key, 1999; Pajumen, 2006).

In this paper, we share the instrumental view of the Stakeholder Theory (Donaldson \& Preston, 1995), in which efficient contracting with stakeholders would maximize conventional firm performance measures (Berman, Wicks, Kotha, \& Jones, 1999; Bosse, Phillips, \& Harrison, 2009; Harrison et al., 2010; Jones, 1995). We also assume the following definitions: (a) stakeholders are 'any group or individual who can affect or is affected by the achievement of a corporation's objectives' (Freeman, 1984, p. 46), such as stockholders, employees, customers, suppliers, local communities, government, and financiers; and (b) stakeholder contracts are "relationships entered into with some degree of freedom and in accord with at least some of the interests of the parties" (Friedman \& Miles, 2002, p. 7). The firm is then seen as a nexus of contracts (Jensen \& Meckling, 1976; Williamson \& Winter, 1991), a focal point of separate bilateral contracts with stakeholders (Hill \& Jones, 1992).

This proposed contractual metaphor is analyzed under the umbrella of the Transaction Cost Economy (TCE) (Williamson, 1985). According to this approach, bounded-rational individuals seek their own interest with guile, giving rise to opportunistic behavior when two parties enter a relationship in which there is asset specificity (Nooteboom, 1993; Williamson, 1975, 1985). The asset specificity is the source of potentially quasi-rents (Klein, Crawford, \& Alchian, 1978; Williamson, 1985). The quasi-rent value of the asset is the excess of its value over its salvage value; as the asset 
become more specific, that is, valuable only in the context of a given relationship, quasi rents are created and therefore the possible gains from opportunistic behavior increases (Klein et al., 1978). The main argument of TCE is that contracts are assigned to appropriate governance structures that curb opportunism, reduce the transaction costs, and make it possible for the parties involved in the relationship to live out the agreement efficiently (Williamson, 1985). Precisely, we argue that reasonable governance costs can be achieved, even in the weak institutional environments of emerging economies, if the firm can succeed in finding the best combination in its stakeholder contractual set. We propose that interacting stakeholders may reduce the costs of curbing opportunism under bounded rationality and uncertainty.

While firm-stakeholder contract types may vary in degree of formality, extent of specificity, frequency, and regularity (Jones, 1995), we focus on relational contracts (Macaulay, 1963; MacNeil, 1978) and we assume the existence of opportunism, bounded rationality, and idiosyncratic investments, in which bilateral governances are found to reduce transaction costs and to promote contract efficiency (Williamson, 1985). For example, firms engaging in philanthropic activities or performing investments to deliver promised environmentally-safe services or products commit themselves to the extent to which the amount transferred to the recipient stakeholder party, or the required dedicated assets, are non-salvageable. This would be seen as a hostage offering (Williamson, 1985), an interest-aligning mechanism or a strategy for selling a claim to the stakeholder, signaling that the firm is not willing to make opportunistic moves (Cornell \& Shapiro, 1987). In exchange, the stakeholder group may commit itself by publicly endorsing the firm's position and indirectly promoting cooperative behavior among its members. This public endorsement is a non-salvageable asset to the extent to which the stakeholder group loses credibility value due to potential contract default.

Although informational disclosures and weak law enforcement in emerging economies tend to increase overall transaction costs (North, 1981), our argument is that interactions among contracting stakeholders reduce transaction costs as they yield synergistic bilateral governances. A firm committed in different $n$ stakeholder contracts will achieve overall mutual cooperation more efficiently if the $n+1$ stakeholder interacts with the existing contracts. Considering that the measurement of stakeholder payoffs in firm contracting is highly uncertain and sensitive to information disclosure about the firm (Cornell \& Shapiro, 1987) and that perceived hostage evaluation is a critical aspect for setting up efficient bilateral governances (Williamson, 1985), stakeholder interaction reduces transaction costs to the extent to which contract defection with the $n+1$ stakeholder would cause previous commitments to lose perceived value. That is, controlling for expropriation problems, firm investments in governance structures to support contracts with the $n+1$ stakeholder will be less costly as the latter perceives that the firm is less likely to default since the costs of contract defection becomes greater than the benefits of opportunism.

Consider the following example as an illustration of how stakeholder interaction yields synergistic bilateral governances and lowers overall transaction costs. A firm that has donated money to community projects would increase its payoffs in investing in social programs for its employees. Since the defection of the employee contract would diminish the efficiency of the cash donated to the community in generating public support, employees may become more willing to cooperate and to positively evaluate firm commitment to their program. The same reasoning applies when previous investments in environmentally-safe facilities would help in achieving public support through cashgiving to the local community.

The condition of interaction effects is central to our argument. A firm would benefit from decreasing marginal costs of governance to the extent to which new stakeholder contracts interact with existing firm-stakeholder contracts. Freeman and Evan (1990) assert that under multilateral contracts, safeguards should be devised as investments in specific assets from one stakeholder affect others. Freeman (1984) and Hill and Jones (1992) call attention to coalitions and cooperation among stakeholders. Plaza-Úbeda, Burgos-Jiménez and Carmona-Moreno (2010) and Rueda-Manzanares, Arago'n-Correa and Sharma (2008) applied the concept stakeholder integration, defined as the ability to establish positive collaborative relationships with a wide variety of stakeholders. Luk, Yau, Tse, Sin 
and Chow (2005) have found empirical support for synergistic effects of multiple stakeholder orientation on firm performance.

One may argue that these efficiency gains are reputation effects of being trustworthy (Jones, 1995). Philanthropy, for example, may be considered a strategy for acquiring an insurance-like protection if the firm defects on a stakeholder contract (Godfrey, 2005). It may also be considered a strategy to build an optimum trust with stakeholders, as the firm tries to create and maintain a context of shared moral character (Wicks, Berman, \& Jones, 1999). Firms that manage for stakeholders develop trusting relationship with them based on principles of distributional, procedural, and interactional justice; and consequently, they can reveal sensitive or private information because of a belief that this information will not be used in a manner that is contrary to their interests (Harrison et al., 2010). When firms increase the level of trust, they reduce the resources needed to create and enforce contracts and eliminate the need for elaborate safeguards and contingencies that require detailed monitoring (Parmar et al., 2010; Post, Preston, \& Sachs, 2002). Finally, such cash-giving strategies can also be regarded as unilateral transaction-specific investments prior to the transaction, signaling to the other party a strong form of trustworthiness (Barney \& Hansen, 1994). Indeed, as opposed to previous applications of contracts in stakeholder theory, we make no claim to any specific moral foundation (Phillips, Freeman, \& Wicks, 2003), such as a broader view of property rights (Donaldson \& Preston, 1995), an integrative social contracts theory (Donaldson \& Dunfee, 1999, 2002) or the Rawlsian social contract argument of fair contracting (Freeman, 1994; Freeman \& Evan, 1990). The reason is straightforward: stakeholder heterogeneity and dynamics favor differential treatments for each group. "While there are still some stakeholder groups whose relationships remain instrumental (due largely to the power they wield), there are other normatively legitimate stakeholders than simply equity shareholders alone" (Phillips et al., 2003, p. 481). The firm should then "distribute the fruits of organizational success (and failure) among all legitimate stakeholders" (Phillips et al., 2003, p. 486); for example, according to the amount each group contributes to the organization. Furthermore, according to Friedman and Miles (2002), as circumstances change, connections among stakeholders become so fragile and their interests so incompatible that normal social rules would be suspended to the point that there would be no contract.

Although we do not subscribe to any moral foundations of stakeholder theory explicitly, we consider they may be operating in the background. Trust, for example, is taken initially in its semistrong form, when contract parties, facing opportunism, bounded rationality, and asset specific investments, are protected through contractual or social forms of governance (Barney \& Hansen, 1994). But we pose no impediments to the idea that some stakeholders' trust can evolve to a strong form of trust, in which exploiting other party's vulnerabilities would violate values, principles, and internalized standards of behavior (Barney \& Hansen, 1994), thus solving commitment problems more efficiently (Jones, 1995).

We do not attempt to generate any testable hypotheses at this level of abstraction. The argument presented in this section is dependent on the context, on the stakeholders involved, and on the commitment strategies deployed for each group. Indeed, contextual variables seem to moderate stakeholder effects on firm performance (Jones, 1995; Wicks \& Berman, 2004). However, if one considers a distribution of possible salient stakeholder contract combinations for a given context, certain arrangements would lead to superior firm performance. We verify the existence of stakeholder interaction effects on firm performance and explore the characteristics of superior contractual sets for domestic firms operating in Brazil. 


\section{Methods}

\section{Firms and stakeholder groups}

We limited our population to publicly traded firms in Brazil to increase data reliability (we excluded financial institutions, controlling groups and holdings). Data on listed firms are subject to verification by independent agencies, which is not the case for self-reported information of non-listed firms. We proceeded carefully in the decision of which stakeholder groups we would model. Instead of randomly choosing from a population of possible stakeholder-firm contracts, we tried to match theoretical arguments with empirically available data. We initially considered eight stakeholder groups: local community groups, natural environment, government (ruling politicians or political parties), political party candidates, suppliers, customers, top management, and employees. To balance parsimony, contextual relevance, external and internal stakeholder groups, we collapsed the initial groups into four broader categories: (a) community (embracing several groups pertaining to the local communities in which a firm operates, and general firm constituents affected by environmental and public support programs, including customers); (b) government (ruling politicians, political party officials and candidates); (c) top management; and (d) employees. We excluded the group of suppliers because of its low empirical relevance to the sampled firms.

The four broad categories of community, government, top management and employees, reflect different kinds of relevant relational contracts for firms in Brazil. Noteworthy is the role of the government. In Brazil, firms and politicians are dependent on each other. Firms depend on politicians because they seek protection and differential treatment in facing political instability, corruption, and intrusion of politics into business affairs. As Pearce (2001) notes, firms under weak, erratic, and hostile governments organize themselves around personal contacts with the powerful, whose relationship nature "is not the positive view of trust among friends ... but rather, closed circles that develop in the face of vulnerability and fear" (Pearce, 2001, p. 37). Politicians depend on firms to finance their political campaigns. The Brazilian electoral system requires great amounts of campaign expenditures in marketing and advertising (usually coming from private firms in exchange for personal services) in order to increase their chances for reelection (Samuels, 2002).

\section{Data Sources and Measures}

We used the best available sources of secondary data to measure firm and stakeholder contract variables: (a) the ECONOMATICA database (Economática, n.d); (b) the Guia EXAME of good corporate citizenship (Revista Exame, 2001, 2002, 2003, 2004); and (c) official data on firm donation in electoral campaigns. The ECONOMATICA database was used to gather accounting and financial data on firm and industry-level variables, as it is a major source of data for business analysts in Brazil. The Guia EXAME, a major publication in the Brazilian business press, publishes self-reported data on firm financing and cash giving on several social and environmental projects. Finally, despite the fact that corporate campaign contributions and donations to political causes have been used elsewhere (Adams \& Hardwick, 1998), anecdotal information about the unreliability of official data of firm financing in political campaigns abounds in Brazil. Even with criticisms, Samuels (2001) indicated that Brazilian official data on campaign financing does not consist of random numbers, and its exploration reveals patterns of correlations among donor firms, sectors, and candidates. Therefore, to attenuate measurement errors and to overcome reliability problems of using self-reported figures, we decided to use binary measures to capture the presence of a firm-stakeholder contract. We assigned ones or zeros to firms, whether it contracted or not with each modeled stakeholder. For instance, if a firm made any contribution, donation, or investment to stakeholder $\left(\mathrm{S}_{1}\right)$, it received a $\mathbf{1}$, otherwise, $\mathbf{0}$. Each firm ended up possessing a set of contracts represented by a 1-0 stream along each of the four stakeholder groups: community, government, top management, and employees. 
We limited our analysis to a five-year time frame, from 2000 to 2004, so it was possible to account for the effects of two elections embracing all levels of Brazilian politics (from the President to city representatives). We acknowledge that a description of recent periods, covering the second and actual term of President Lula, would be appreciated. However, the purpose of this paper is not to fill any empirical gap, rather is to robustly explore conceptual relationships among stakeholder interaction and firm performance. We believe that this theoretical gap is adequately investigated in the sampled period of the paper.

The Guia EXAME provided yearly data from 2000 to 2004 . To average stakeholder data, we attributed 1 to a firm that had made any stakeholder donation or investment, in at least one of the sampled years. As for the top management stakeholder, we considered a firm having relationships with this group if it undertakes considerable agency efforts measured indirectly by its ownership concentration (we attributed 1 for firms possessing less than $50 \%$ of stocks in the hands of the main shareholder). Our operationalization is coherent with the arguments of the positivist agency theory (Fama \& Jensen, 1983; Jensen \& Meckling, 1976), which also share the contractual metaphor, between the principal and agent, in which the former pursues efforts to control and monitor the latter (Eisenhardt, 1989), which is magnified if there is weak property rights enforcement (La Porta, Lopezde-Silanes, \& Shleifer 1999). Despite the fact that the board of directors is an important governance tool, ownership is another governance mechanism that governs and controls managerial action (Connelly, Hoskisson, Tihanyi, \& Certo, 2010). Table 1 shows detailed operational definitions for each measured variable.

Table 1

\section{Operational Definitions of Observed Variables}

\begin{tabular}{|c|c|}
\hline Variable & Operational Definition \\
\hline Comm & $\begin{array}{l}\text { Coded } 1 \text { for a firm who had participated in at least one project involving senior citizens, } \\
\text { children and teenagers, handicapped, community, culture, health and education, natural } \\
\text { environment, and social volunteers, in any year between } 2000 \text { and } 2004 \text {. Coded } \mathbf{0} \\
\text { otherwise. }\end{array}$ \\
\hline Government & $\begin{array}{l}\text { Coded } 1 \text { for a firm who had donated to at least one political party or candidate, in any } \\
\text { election campaign between } 2000 \text { and } 2004 \text {; independent of if the recipient candidate won } \\
\text { the election. Coded } \mathbf{0} \text { otherwise. }\end{array}$ \\
\hline Employees & $\begin{array}{l}\text { Coded } \mathbf{1} \text { for a firm who had participated in at least one project involving its employees in } \\
\text { any year between } 2000 \text { and } 2004 \text {. Coded } \mathbf{0} \text { otherwise. }\end{array}$ \\
\hline Top Mar & $\begin{array}{l}\text { Coded } 1 \text { for a firm who had undertaken considerable agency efforts. To proxy for this } \\
\text { construct, we used ownership concentration, measured by the percentage of stocks in } \\
\text { possession of the major stockholder, and averaged for the five-year period. We defined } \\
\text { the threshold of } .5 \text { to assign } 1 \text { or } \mathbf{0} \text { to a firm, based on the inference that less concentrated } \\
\text { firms (code 1). }\end{array}$ \\
\hline Firm Performance & $\begin{array}{l}\text { Return on Equity (ROE), the ratio of net profit to equity. We used this measure to } \\
\text { account for the shareholders' return. Three other indicators were used for comparative } \\
\text { purposes: Operational Return on Assets (ROA), measured by the ratio of operation } \\
\text { income to total assets; price-to-book, as the ratio of stock price to its book value; and } \\
\text { growth, the percentage variation of ROE from } 2000 \text { to } 2004 \text {. All figures were averaged } \\
\text { yearly values from } 2000 \text { to } 2004 \text {. }\end{array}$ \\
\hline Industry Effects & $\begin{array}{l}\text { Usual control variable for firm performance. We used an average value for the } \\
\text { operational Return on Assets, for each aggregate of firms composing an industry. The } \\
\text { ECONOMATICA database defines an industry according to product characteristics. }\end{array}$ \\
\hline Size & $\begin{array}{l}\text { Usual control variable for firm performance. It is the yearly average of firm total assets } \\
\text { (in } 1,000 \text { US\$), considering the four-year time frame (2000-2004). A log transformation } \\
\text { was used to achieve univariate normal distribution. }\end{array}$ \\
\hline
\end{tabular}




\section{Data analysis}

We followed a three-stage analysis process to explore the effects of stakeholder interactions on firm performance. First, we clustered firms according to similar patterns of stakeholder contracting behavior. We aimed to understand which contracts appeared together for the most part and which do not. In the second stage, we produced nine estimates of the general linear model of firm performance described in Equation 1 using the cluster solutions as the independent factor we called stakeholder contracting $\left(\varphi_{t}\right)$. Each cluster solution provided $t$ levels (the number of clusters in the solution) for this fixed factor. Each level represented a specific configuration of stakeholder contracts. How much level differences matter in explaining firm performance was given by estimates of $\varphi_{t}$. The 4-year average annual Return-on-Equity (ROE) was initially used as the firm performance indicator. Coefficients for firm size (log of average firm total assets) and industry effects (average operational Return-on-Assets for each industry) were also modeled to account for usual controls in Strategy research. Finally, in the third stage, we investigated cluster level differences for the best model solution in Equation 1 and also explored the characteristics for the best contractual set.

$$
\text { Firm Performance }=\beta_{0}+\beta 1 \text { Size }+\beta 2 \text { Industry Effects }+\varphi t+\varepsilon
$$

We posed no a priori hypothesis concerning which level of interaction, or among which stakeholder groups, stakeholder contracting would impact firm performance. Instead of using main effects and interaction effects in a multivariate regression, the analysis of performance differences across patterns in stakeholder contracting behavior seemed more suitable. To ensure robustness we compared the best solution for Equation 1 with other economic and market performance indicators. We also analyzed the impact of grouping firms from different industries and sizes on the cluster membership effect on firm performance.

Comments on how we handled possible influential observations in the analysis are needed. From the initial population of firms, we excluded financial institutions because their high leverage ratios tend to inflate some shareholder performance indicators, such as Return on Equity. We also excluded controlling groups and holdings with no operational revenue. We assessed influential observations for outlier treatment by cross-examining the results from several methods. We eliminated univariate outliers (3 standard-deviations) and multivariate outliers (Cook's distance and regression residuals).

From the original 351 firms, our final sample consisted of 267 firms for the ROE model, after excluding for aberrant data, influential and missing data. Missing data did not seem to be a problem and departures from normality were not severe, although performance indicators did not present a normal distribution (chi-square test). However, a lack of normality was rather compensated for by a somewhat large sample. General Linear Model assumptions, such as homogeneity of variance, colinearity among factors and covariates, and linearity were fairly satisfied (Hair, Anderson, Tatham, $\&$ Black, 1995). When compared to the final sample data, excluded firms did not show strong patterns of size or industry, which signaled a non-severe survivorship bias (Brown, Goetzmann, Ibbotson, \& Ross, 1992). SPSS procedures were applied in all three stages.

\section{Research Findings}

We initially used the original sample of 351 firms to cluster firms using the binary stakeholder contract data for the government, community, and employees' groups, and 339 firms for the top management group, since 12 missing values were reported. From Table 2, government, top management and community were the most frequent individual contracts. However, the majority of firms did not have contracts with any modeled stakeholder. 
Table 2

Frequency Distributions for Individual Stakeholder Contracts

\begin{tabular}{ccccc}
\hline Code & Government & Community & Employees & Top Management $^{\#}$ \\
\hline 1 (contract) & 100 & 74 & 11 & 84 \\
0 (no contract) & 251 & 277 & 340 & 255 \\
\hline
\end{tabular}

Note. ${ }^{\#}$ Data was missing for this variable in 12 firms.

\section{Model estimations}

We set hierarchical cluster solutions to range from two to 10 clusters, using Ward's Method for cluster formation and squared Euclidian distances for binary data measurement. Outliers and colinearity did not seem to be a problem for all solutions, despite the large number of zeros. Ward's method was chosen because it tends to produce groups with a similar number of firms (Hair et al., 1995). In a given solution, each cluster represented a pattern in stakeholder contracting. We estimated the model in Equation 1 for each one of the nine cluster solutions with its respective number of clusters, i.e. the $t$ value for the factor stakeholder contracting. We constrained the original sample to 267 firms after excluding influential and missing data. Table 3 shows the adjusted R-squared for the nine estimations of Equation 1, along with the respective number of firms in each cluster.

Table 3

Cluster Sizes and Adjusted R-Squared for Each Model Solution

\begin{tabular}{|c|c|c|c|c|c|c|c|c|c|}
\hline$\left(\right.$ Model$\left.^{*}\right)$ & (1) & (2) & (3) & (4) & (5) & (6) & (7) & (8) & (9) \\
\hline Adj. $R^{2}(\%)$ & $6.5 \%$ & $7.6 \%$ & $7.3 \%$ & $8.9 \%$ & $9.4 \%$ & $9.4 \%$ & $9.8 \%$ & $9.9 \%$ & $9.7 \%$ \\
\hline$\#$ of clusters & 2 & 3 & 4 & 5 & 6 & 7 & 8 & 9 & 10 \\
\hline$t=1$ & $113^{\#}$ & 50 & 50 & 50 & 16 & 16 & 16 & 16 & 16 \\
\hline$t=2$ & 154 & 63 & 32 & 30 & 30 & 16 & 16 & 24 & 24 \\
\hline$t=3$ & & 154 & 63 & 33 & 34 & 34 & 34 & 34 & 34 \\
\hline$t=4$ & & & 122 & 32 & 33 & 17 & 8 & 8 & 4 \\
\hline$t=5$ & & & & 122 & 32 & 32 & 32 & 32 & 32 \\
\hline$t=6$ & & & & & 122 & 30 & 9 & 9 & 9 \\
\hline$t=7$ & & & & & & 122 & 30 & 6 & 16 \\
\hline$t=8$ & & & & & & & 122 & 16 & 4 \\
\hline$t=9$ & & & & & & & & 122 & 122 \\
\hline$t=10$ & & & & & & & & & 138 \\
\hline
\end{tabular}

Note. *Model: $\mathrm{ROE}=\beta 0+\beta 1$ Size $+\beta 2$ Industry Effects $+\varphi \mathrm{t}+\varepsilon$ \#Table cells are cluster sizes measured by number of firms.

We elected Model 4, with five clusters, as the best solution for the following reasons: (a) models 5 through 9 did not show homogeneity in group variance across the $t$ levels of factor $\varphi_{t}$; (b) there were relatively small clusters in models 7 through 9; (c) increases in adjusted R-squared from model 5 to model 6 was almost null; and (d) model 4 had a good balance among cluster sizes and adjusted Rsquared. In our elected model, stakeholder contracting $\left(\varphi_{t}\right)$ is a 5-level factor, statistically significant ( $p$ $<.015$ ), as shown in Table 4. 
Table 4

Tests of Between-Subject Effects for Model 4

\begin{tabular}{lccccc}
\hline \multicolumn{1}{c}{ Source\# } & Type III SS & $\begin{array}{c}\text { Degrees of } \\
\text { freedom }\end{array}$ & Mean Square & F & Sig. \\
\hline Corrected Model & 9323.57 & 6 & 1553.929 & 5.325 & .000 \\
Intercept & 1004.806 & 1 & 1004.806 & 3.442 & .065 \\
Size & 1002.525 & 1 & 1002.525 & 3.435 & .065 \\
Industry Effects & 2359.853 & 1 & 2359.853 & 8.086 & .005 \\
Stakeholder contracting & 3695.294 & 4 & 923.823 & 3.166 & .015 \\
Error & 75875.657 & 260 & 291.829 & & \\
\hline
\end{tabular}

Note. \# ROE is the dependent variable

\section{Contracting pattern differences}

A close examination of level differences in stakeholder contracting in Model 4 is worth making. The contracting patterns of the five clusters of Model 4 are summarized in Table 5, which shows the distribution of the number of contracts in each cluster. Cluster 3, with 33 firms, was the only contract arrangement in which all stakeholders were presented. All firms in this cluster have contracts with both government and community, and some of them also have contracts with employees and/or top management. Looking to row percentages, $80 \%$ of total employee contracts, and $20 \%$ of total top management contracts appeared together with government and community. Government and community were, therefore, the major influences upon this cluster. They may be thought of as a basic structure upon which contracting with top management and especially employees may be achieved more efficiently. Cluster 5, the largest group, indicated a group of firms possessing no contracts; so we set it as the reference cluster.

Table 5

Distribution of Stakeholder Contracts for each Cluster in Model 4

\begin{tabular}{lcccccc}
\hline \multirow{1}{*}{ Stakeholder } & $\begin{array}{c}\text { Cluster 1 } \\
\text { 50 firms }\end{array}$ & $\begin{array}{c}\text { Cluster 2 } \\
\text { 30 firms }\end{array}$ & $\begin{array}{c}\text { Cluster 3 } \\
\text { 33 firms }\end{array}$ & $\begin{array}{c}\text { Cluster 4 } \\
\text { 32 firms }\end{array}$ & $\begin{array}{c}\text { Cluster 5 } \\
\text { 122 firms }\end{array}$ & TOTAL \\
\hline \multirow{2}{*}{ Community } & 0 & 30 & 33 & 0 & 0 & \multirow{2}{*}{63} \\
Government & $(0)^{\#}$ & $(48)$ & $(52)$ & $(0)$ & $(0)$ & \\
\multirow{2}{*}{ Employees } & 50 & 0 & 33 & 0 & 0 & 83 \\
\multirow{2}{*}{ Top Management } & $(60)$ & $(0)$ & $(40)$ & $(0)$ & $(0)$ & \\
& 0 & 2 & 8 & 0 & 0 & \multirow{2}{*}{10} \\
& $(0)$ & $(20)$ & $(80)$ & $(0)$ & $(0)$ & \\
\hline
\end{tabular}

Note. \# Numbers in parentheses are row percentages

Considering the contracting pattern in Table 5, we labeled Cluster 1 the Government cluster; Cluster 2, the Community cluster; the third, the Government-Community cluster; the fourth, the Top management cluster; and cluster 5, the Non-stakeholder cluster. From estimates of Model 4, we tested for firm performance average differences and coefficient contrasts across the five clusters, controlling 
for the covariates, size, and industry effects. Table 6 shows the results. The Government-Community cluster showed the greatest adjusted average for firm performance measured by ROE, 14.95\%, against the lowest values, $3.11 \%$ and $3.15 \%$, for Government and Non-stakeholder clusters, respectively. The Government-Community cluster was the only one whose average was statistically different from all the others and it showed the only significant coefficient. An average firm possessing at least Government-Community contracts would have a ROE 11.79 percentage points greater than the average firm possessing no contracts. These results suggest that, controlling for the usual effects of firm size and industry, contracting at least with government and community together would yield superior firm performance. No other contract combination in this model solution showed significant improvement on firm profitability.

Table 6

Estimated Cluster Averages and Coefficient Contrast Tests for Model 4

\begin{tabular}{lccc}
\hline Clusters & Average* $^{*}$ & Coefficient $^{\#}$ & Test Power $^{\#}$ \\
\hline 1 (Government) & 3.115 & -.0375 & .05 \\
& $(2.432)$ & $(.990)$ & \\
2 (Community) & 4.700 & 1.548 & .07 \\
3 (Government-Community) & $(3.203)$ & $(.667)$ & \\
& 14.950 & 11.798 & .93 \\
4 (Top Management) & $(3.048)$ & $(.001)$ & \\
& 3.206 & .0543 & .05 \\
5 (No-stakeholder) & $(3.046)$ & $(.987)$ & \\
& 3.152 & n.a & n.a. \\
\hline
\end{tabular}

Note. ${ }^{*}$ Figures are average value of ROE for each cluster. Standard errors are in parentheses; ${ }^{\#}$ Coefficient values are based on reference cluster Non-stakeholder. P-values are in parentheses; ${ }^{\# \#}$ Observed power of the coefficient test (alpha $=.05$ )

\section{Verifying robustness}

We tested the robustness of performance superiority of the Government-Community cluster by estimating Model 4 with different performance indicators and by investigating possible confounding variables. First, we tested for cluster differences using Operational ROA, Price-to-Book, and Profitability Growth as dependent variables. Looking at Table 7, besides ROE, only the Operational ROA model was found to be significant $(p<.10)$ and showed a better adjusted R-square of $12.9 \%$. In both models, only the Government-Community cluster showed a significant coefficient. Results suggest that firm membership to the Government-Community cluster has a greater positive impact on the returns on equity (11.798) than to the operational returns on assets (3.30). Differences in stakeholder contracting did not seem to affect market expectations, as the price-to-book model was not significant $(p<.197)$. Stakeholder contracting also did not show an effect on profitability growth, implying that the superior performance of Government-Community firms were persistent over the period. If one argues that stakeholder interaction among government and community do not cause superior performance, it may at least contribute to its maintenance. We also tested a competing model with direct effects for the individual stakeholder groups. No direct effect was significant. Adjusted Rsquare was $5.7 \%$, lower than $8.9 \%$ for Model 4 . Finally, we applied several split samples to verify the persistence of our findings. Results indicated a good stability, in which findings were replicated in more than $50 \%$ of the attempts (small sample sizes contributed to diminish significance). We did not find any confounding effects of intra-cluster differences as clusters did not differ each other with respect to firm size and industry membership. 
Table 7

Average Performance Cluster Differences for Comparative Analysis

\begin{tabular}{lccccccc}
\hline $\begin{array}{c}\text { Dependent } \\
\text { Variable }\end{array}$ & Government & Community & $\begin{array}{c}\text { Government- } \\
\text { Community* }\end{array}$ & $\begin{array}{c}\text { Top } \\
\text { management }\end{array}$ & $\begin{array}{c}\text { Non- } \\
\text { stakeholder }\end{array}$ & $\begin{array}{c}\text { p-value } \\
\text { of } \varphi_{t}\end{array}$ & Adj. R ${ }^{2}$ \\
\hline ROE (\%) & 3.115 & 4.700 & $\begin{array}{c}14.95 \\
(11.798)\end{array}$ & 3.206 & 3.152 & .015 & $8.9 \%$ \\
$\begin{array}{l}\text { Operational } \\
\text { ROA (\%) }\end{array}$ & 8.82 & 7.68 & $\begin{array}{c}11.80 \\
(3.300)\end{array}$ & 7.49 & 8.49 & .067 & $12.9 \%$ \\
Price-to-book & 1.34 & 0.974 & $\begin{array}{c}1.917 \\
(0.754)\end{array}$ & 1.298 & 1.163 & .197 & $1.2 \%$ \\
$\begin{array}{l}\text { Growth } \\
(2000-2004)\end{array}$ & 2.97 & 3.78 & 0.14 & -0.08 & -0.96 & .980 & $0.0 \%$ \\
\hline
\end{tabular}

Note. * Values in parentheses are significant coefficients $(\mathrm{p}<.05)$. Non-stakeholder is the reference cluster.

Possible confounding effects for size and industry were also analyzed. One may argue that performance superiority of the Government-Community cluster would come from large firms or from firms in profitable industries pertaining to this cluster. Even though size and industry were modeled in Equation 1, we conducted separate one-way ANOVA tests to investigate cluster differences in these two variables. Post-hoc tests showed that the average size values for Community and GovernmentCommunity clusters were significantly greater than values of the other three groups. However, firms in the Community cluster did not differ statistically in size than those in the Government-Community cluster. Industry average profitability was not found to be statistically different among clusters $(\mathrm{p}<.686)$. Firm performance superiority of the Government-Community cluster could not be attributed to intra-cluster industry features. Firm size and industry did not seem to confound results.

\section{Discussion}

The effects of stakeholder orientation on firm performance have long been studied indirectly in Corporate Social Performance models (Barnett, 2007; Clarkson, 1995; Griffin \& Manhon, 1997; McGuire, Sundgren, \& Schneeweis, 1988; Waddock \& Graves, 1997), and more recently in Business and Ethics (Berman et al., 1999; Hillman \& Keim, 2001; Jones \& Wicks, 1999), Marketing (Bhattacharya \& Korschun, 2008; Greenley \& Foxall, 1997), Strategic Management (Bosse et al., 2009; Choi \& Wang, 2009; Clarke, 1998; Harrison et al., 2010) and Management literatures (Galbreath, 2006). In Finance, stakeholder theory is used to explain increases in profitability (Parmar et al., 2010; Smith, 2003) and capital structure decisions (Istaitieh \& Rodriquez-Fernandez, 2006). However, the empirical modeling of stakeholder interaction effects is still scarce (Luk et al., 2005). Based on a contractual metaphor, we argue that interaction among stakeholder contracts would permit firms to set up synergistic governance structures in order to more efficiently access valuable external resources in an emerging economy setting. A firm may profit from these economies of scope to the extent to which there is a resonance among the perceived values of the offered hostages in its stakeholder contractual set (Williamson, 1985) or among the implicit claims sold by the firm (Cornell \& Shapiro, 1987).

Using a sample of publicly traded firms in Brazil, we explored different patterns in firm contracting with the following stakeholder groups: Community, Government, Top management, and Employees. We found positive stakeholder interaction effects on firm performance measured by operational and financial profitability indicators. Firms contracting at least with the Government and Community were found to benefit from superior firm performance. No other combination, or any 
single contract, appeared to produce effects on firm performance. This result converges with previous empirical researches, which reported the importance of balancing multiple stakeholder interests and the synergistic effects of stakeholder groups on firm performance (Greenley \& Foxall, 1997; Luk et al., 2005). It also suggests that the contractual metaphor we advance here is a suitable framework to analyze stakeholder management.

The positive connection between Government-Community contracts and firm performance may come from three sources. First, we found that stakeholder contracting effects on ROE was greater than effects on Operational ROA (Table 7). This suggests the importance of managing stakeholder interactions to efficiently access valuable resources that affect the capital structure of the firm. Government and community contracts make possible efficient access to debt financing from both private and state-owned institutions. Since interest rates in Brazil are among the highest in the world, debt financing is an important issue for domestic firms. In this case, private banks may positively recognize previous firm investments in social and environmental projects when assessing loan risks. Public financing is often subject to political influences. Claessens, Feijem and Laeven (2008) found that firms connected to politics through campaign financing in Brazil have shown superior access to debt financing and experienced higher stock returns than firms that did not provide contributions to politicians running for the 1998 and 2002 elections. Instead of promoting the reduction of transaction costs, government intervention in financial markets like in Brazil is viewed as an instrument for politicians to bargain for political support and personal interests (Dinç, 2005; Sapienza, 2004). Indeed, recent research has reported the influence of political interests in shaping the Banking field in transition economies (Tihanyi \& Hegarty, 2007).

The second theoretical mechanism of the stakeholder interaction effect on firm performance may be described looking at the results shown in Table 5. Most of the firms in Cluster 3 (GovernmentCommunity) also have contracts with employees and/or top management. This suggests that government and community contracts form a basic structure upon which overlapping governance structures may be built, reducing the overall firm-stakeholder transaction costs. That is, firms possessing contracts with government and community may achieve mutual cooperative behavior with employees and/or top management more efficiently. It is clear that investments in projects for the local community also generate benefits for employees, including the top management team. Considering that there is a reputational effect, or a strong form of trust (Barney \& Hansen, 1994; Jones, 1995), these firms may be more efficient in attracting better human resources. Contracting with the government also interacts with the top management team. Good relationships between the firm and the government through top management individuals (Goldman, Rocholl, \& So, 2009; Hillman, 2005; Faccio, 2006) may pressure the legislator to pass favorable regulation or labor laws that have an impact on operational cost reductions related to labor, or raising rivals' costs (McWilliams, Fleet, \& Cory, 2002). In Brazil, there are several anecdotal cases about firms that moved their plants to regions subsidized by state governments; for example, southern shoe manufacturers producing in the northeast.

Finally, the third mechanism explaining our results comes from insights from agency theory (Eisenhardt, 1989; Fama \& Jensen 1983; Jensen \& Meckling 1976). According to this theory, firms face agency costs due to information asymmetries and different utility functions between the shareholder (principal) and the top managers (agent). Shareholders and managers have different access to firm-specific information and divergent risk preferences. In a world of information asymmetries, principal and agent have different reactions towards risk. In the principal-agent theory (Harris \& Raviv, 1978), the principal is more prone to take risks than the agent because of his capacity to diversify investments.

Firms with less concentrated ownership faces more agency costs because managerial control is more difficult and shareholders are more likely to face opportunistic behavior from the managers and the principal limits divergences by establishing incentives for the agent and pays to expend resources, the so-called bonding costs (Jensen \& Meckling, 1976). On the other hand, our claim is that if these firms succeed in having contracts with both government and community, agency costs are reduced. One implication of stakeholder theory to agency theory is that the former provides a larger perspective 
for firm contracts than the usual shareholder-manager contract of the latter. That is, top managers also have obligations to other stakeholders, mitigating self dealing and help curbing opportunism (Phillips et al., 2003). When managing for stakeholders, the firm develops and nurtures trust-based relationships, and shares more information with stakeholder groups, who contribute to resource allocation (Harrison et al., 2010).

However, stakeholder theory should not be an excuse for managerial opportunism (Jensen, 2000). Agency theory helps inform stakeholder theory through the notions of optimal contracting and reduction of agency costs (Phillips et al., 2003; Shankman, 1999). On the other hand, agency theory and its formal control mechanisms are less flexible and more conservative (Mcevily, Perrone, \& Zaheer, 2003), and it may learn from stakeholder theory to be more prone to risk and innovation.

The positive relationship between Government-Community contracts and firm performance has three implications for theorizing about strategies of domestic firms competing in emerging economies. First, as Wright et al. (2005) show, Resource-Based research emphasizes two types of resource flexibility to cope with environmental turbulence: flexibility of inputs and in using the resources. We argue that focusing on resource flexibility drives attention away from resource acquisition and external dependency issues, e.g. the importance of having superior access to inputs through stakeholder contracting. Second, the view of the firm as a bundle of governances (Barney \& Hansen, 1994) of synergistic firm-stakeholder contracts may also serve as an alternative to fill in the institutional void (Khanna \& Palepu, 2000), as firms acting close to governments and communities may attract good transacting partners and efficiently access rare, valuable country resources (Wan, 2005), reducing ex ante and ex post transactions costs (Williamson, 1985). Differently from recent empirical research on business groups (Yiu, Bruton, \& Lu, 2005), we found that government proximity, aligned with investments in community projects, may foster synergistic governance structures to manage stakeholder contracting, overcoming information asymmetry problems. Third, the evidence we present in the Brazilian case indicate the importance of testing empirical models of stakeholder interaction effect on firm performance while coping with major shortcomings of data collection and reliability (Hoskisson et al., 2000).

Although this study contributes to our knowledge on the relationships between stakeholder interaction and competition of domestic firms in emerging markets, there are some limitations that need to be taken into account. First, stakeholder groups were not defined a priori but they were sample specific. Indeed, emerging economies are a heterogeneous group (Hoskisson et al., 2000) and any generalization attempt would need caution. However, the argument of conjoint stakeholder effect on firm performance holds and provides insights for understanding strategy in these settings.

Second, this research has an exploratory nature and its ex post rationale may suggest an add-on effect. That is, the more stakeholder contracts the better. In fact, a new stakeholder relationship would be welcome only if stakeholder interactions concerning the perceived values of hostages offered in the relationships were present in the contractual set.

Third, our stakeholder group definitions collapsed several stakeholder groups into broad categories. In the absence of better data, we avoided using figures in self-reported measures, but we had to rely on broad defined groups, such as community (Dunhan, Freeman, \& Liedtka, 2006) due to data availability. Where reliable data is available, further research should control for differences between business-to-business firms and business-to-consumer firms, as well as between unionized or non-unionized employees and even discriminating among different top management teams. Indeed, finer-grained measures of stakeholder groups are welcome (Harrison \& Freeman, 1999). Another limitation about grouping comes from the fact that each stakeholder group clusters firms from several industries and that would confound results. However, we did not find any statistical differences of industry averages among clusters.

Finally, the model did not achieve an overall good fit (12.9\% in the operational ROA model), which would lead to large prediction errors. However, the main purpose of this paper was not prediction, but rather the explanation of stakeholder contracting effects on firm performance. Future 
models would try to use other covariates such as past performance, capital structure variables (Cornell \& Shapiro, 1987) or strategy-related variables in a moderation model (Berman et al., 1999).

\section{Conclusion}

We advanced a contract-based argument to understand how firms can efficiently relate to external actors. Stakeholder contracting helps firms overcome market failures and information disclosure problems. It is the stakeholder conjoint effect that matters, and developing the right combination of stakeholder contracts can be a source of sustainable competitive advantage among domestic firms in emerging economies.

We learn from our Brazilian data that firm contracts with at least both government and community showed a positive impact on firm performance. Powerful external actors, such as the government, may provide protection and privileged information. Along with investments in community contracts, firms may benefit from superior access to both public and private financing, a crucial variable for firm performance in hostile emerging market environments.

Our study also informs managerial practice. Managers should consider that any decision of investing in stakeholder relationships need to take into account how different combinations of 'firmstakeholder contracts' impact firm performance. Strategy research would benefit from focusing on resource acquisition issues and how stakeholders can serve as valuable suppliers. We hope future research may benefit from these insights in search for a better understanding of the strategy phenomena and firm performance in emerging economies.

\section{Received 26 October 2009; received in revised form 13 October 2010.}

\section{References}

Adams, M., \& Hardwick, P. (1998). An analysis of corporate donations: United Kingdom evidence. Journal of Management Studies, 35(5), 641-654. doi: 10.1111/1467-6486.00113

Bandeira-de-Mello, R., \& Marcon, R. (2006). Heterogeneidade do desempenho de empresas em ambientes turbulentos. Revista de Administração de Empresas, 46(2), 34-43. doi: 10.1590/S0034-75902006000200004

Barnett, M. L. (2007). Tarred and untarred by the same brush: exploring interdependence in the volatility of stock returns. Corporate Reputation Review, 10(1), 3-21. doi: $10.1057 /$ palgrave.crr.1550035

Barney, J., \& Hansen, M. (1994). Trustworthiness as a source of competitive advantage. Strategic Management Journal, 15(Suppl.), 175-190. doi: 10.1002/smj.4250150912

Berman, S., Wicks, A., Kotha, S., \& Jones, T. (1999). Does stakeholder orientation matter? The relationship between stakeholder management models and firm financial performance. Academy of Management Journal, 42(5), 488-506. doi: 10.2307/256972

Bhattacharya, C. B., \& Korschun, D. (2008). Stakeholder marketing: beyond the four ps and the customer. Journal of Public Policy \& Marketing, 27(1), 113-116. doi: 10.1509/jppm.27.1.113

Bosse, D. A., Phillips, R. A., \& Harrison, J. S. (2009). Stakeholders, reciprocity, and firm performance. Strategic Management Journal, 30(4), 447-456. doi: 10.1002/smj.743 
Brito, L. A. L., \& Vasconcelos, F. C. (2004). A heterogeneidade do desempenho, suas causas e o conceito de vantagem competitiva: proposta de uma métrica [Special Issue]. Revista de Administração Contemporânea, 8, 107-129. doi: 10.1590/S1415-65552004000500007

Brito, L. A. L, \& Vasconcelos, F. C. (2005). Desempenho das empresas brasileiras: efeitos ano, ramo de negócios e firma individual [Special Issue]. Revista de Administração Contemporânea, 9, 6585. doi: 10.1590/S1415-65552005000500004

Brown, S., Goetzmann, W., Ibbotson, R., \& Ross, S. (1992). Survivorship bias in performance studies. The Review of Financial Studies, 5(4), 553-580. doi: 10.1093/rfs/5.4.553

Carvalho, C. E., Bandeira-de-Mello, R., Vianna, S. L. G., \& Marcon, R. (2009). Performance heterogeneity in Latin America: an investigation into the transient effects of country of origin. Latin American Business Review, 10(4), 289 - 308. doi: 10.1080/10978520903280604

Choi, J., \& Wang, H. (2009). Stakeholder relations and the persistence of corporate financial performance. Strategic Management Journal, 30(8), 895-907. doi: 10.1002/smj.759

Claessens, S., Feijen, E., \& Laeven, L. (2008). Political connections and preferential access to finance: the role of campaign contributions. Journal of Financial Economics, 88(3), 554-580. doi: 10.1016/j.jfineco.2006.11.003

Clarke, T. (1998). The stakeholder corporation: a business philosophy for the information age. Long Range Planning, 31(2), 182-194. doi: 10.1016/S0024-6301(98)00002-8

Clarkson, M. (1995). A stakeholder framework for analyzing and evaluating corporate social performance. The Academy of Management Review, 20(1), 92-117. doi: 10.2307/258888

Connelly, B. L., Hoskisson, R., Tihanyi, L., \& Certo, S. T. (2010). Ownership as a form of corporate governance. Journal of Management Studies, 48(8), 1-27. doi: 10.1111/j.14676486.2010.00929.x

Cornell, B., \& Shapiro, A. (1987). Corporate stakeholders and corporate finance. Financial Management, 16(1), 5-14. doi: 10.2307/3665543

Dinç, I. (2005). Politicians and banks: political influences on government-owned banks in emerging markets. Journal of Financial Economics, 77(2), 453-479. doi: 10.1016/j.jfineco.2004.06.011

Donaldson, T., \& Dunfee, T. (1999). Ties that bind. Boston: Harvard Business School Press.

Donaldson, T., \& Dunfee, T. (2002). Ties that bind in business ethics: social contracts and why they matter. Journal of Banking \& Finance, 26(9), 1853-1865. doi: 10.1016/S0378-4266(02)00195-4

Donaldson, T., \& Preston, L. (1995). The stakeholder theory of the corporation: concepts, evidence and implications. The Academy of Management Review, 20(1), 65-91. doi: 10.2307/258887

Dunhan, L., Freeman, R., \& Liedtka, J. (2006). Enhancing stakeholder practice: a particularized exploration of community. Business Ethics Quarterly, 16(1), 23-42.

Economática - Tools for investments analysis. (n.d.). Base de dados [CD-ROM]. São Paulo: Author.

Eisenhardt, K. (1989). Agency theory: an assessment and review. The Academy of Management Review, 14(1), 57-74. doi: 10.2307/258191

Faccio, M. (2006). Politically connected firms. The American Economic Review, 96(1), 369-386. doi: $10.2139 / \mathrm{ssrn} .444960$

Fama, E. F., \& Jensen, M. C. (1983). Separation of ownership and control. Journal of Law and Economics, 26(2), 301-325. doi: 10.1086/467037 
Farashahi, M., \& Molz, R. (2004). A framework for multilevel organizational analysis in developing countries. International Journal of Commerce \& Management, 14(1), 59-78. doi: $10.1108 / 10569210480000174$

Freeman, R. (1984). Strategic management: a stakeholder approach. Boston: Pitman.

Freeman, R. (1994). The politics of stakeholder theory: some future directions. Business Ethics Quarterly, 4(4), 409-421.

Freeman, R., \& Evan, W. (1990). Corporate governance: a stakeholder interpretation. The Journal of Behavioral Economics, 19(4), 337-359. doi: 10.1016/0090-5720(90)90022-Y

Friedman, A., \& Miles, S. (2002). Developing stakeholder theory. Journal of Management Studies, 39(1), 1-21. doi: 10.1111/1467-6486.00280

Galbreath, J. (2006). Does primary stakeholder management positively affect the bottom line? Some evidence from Autralia. Management Decision, 44(8), 1106-1121. doi: $10.1108 / 00251740610690649$

Godfrey, P. (2005). The relationship between corporate philanthropy and shareholder wealth: a risk management perspective. The Academy of Management Review, 30(4), 777-798. doi: $10.2307 / 20159168$

Goldman, E., Rocholl, J., \& So, J. (2009). Do politically connected boards affect firm value? Review of Financial Studies, 22(6), 2331-2360. doi: 10.1093/rfs/hhn088

Goldszmidt, R. G. B., Brito, L. A. L., \& Vasconcelos, F. C. de (2007). O efeito país sobre o desempenho da firma: uma abordagem multinível. Revista de Administração de Empresas, 47(1), 12-23. doi: 10.1590/S0034-75902007000100003

Greenley, G., \& Foxall, G. (1997). Multiple stakeholder orientation in UK companies and the implications for company performance. Journal Management Studies, 34(2), 259-284. doi: $10.1111 / 1467-6486.00051$

Griffin, J., \& Mahon, J. (1997). The corporate social performance and corporate financial performance debate. Business and Society, 36(1), 5-31. doi: 10.1177/000765039703600102

Griffiths, A., \& Zammuto, R. F. (2005). Institutional governance systems and variations in national competitive advantage: an integrative framework. Academy of Management Review, 30(4), 823842. doi: $10.5465 / A M R .2005 .18378880$

Guillén, M. (2000). Business groups in emerging economies: a resource-based view. Academy of Management Journal, 43(3), 362-380. doi: 10.2307/1556400

Hair, J., Anderson, R., Tatham, R., \& Black, W. (1995). Multivariate data analysis (5th ed.). New Jersey: Prentice-Hall, Inc.

Harris, M., \& Raviv, A. (1978). Some results on incentive contracts with applications to education and employment, health insurance, and law enforcement. American Economic Review, 68(1), 20-30.

Harrison, J. S., Bosse, D. A., \& Phillips, R. A. (2010). Managing for stakeholders, stakeholder utility functions and competitive advantage. Strategic Management Journal, 31(1), 58-74. doi: $10.1002 / \mathrm{smj}$

Harrison, J. S., \& Freeman, R. (1999). Stakeholders, social responsibility and performance: empirical evidence and theoretical perspectives. Academy of Management Journal, 42(5), 479-485. doi: $10.2307 / 256971$ 
Heugens, P., Oosterhout, H., \& Vromen, J. (Eds.). (2004). The social institutions of capitalism: evolution and design of social contracts. London: Edward Elgar.

Hill, C., \& Jones, T. (1992). Stakeholder-agency theory. Journal of Management Studies, 29(2), 131154. doi: 10.1111/j.1467-6486.1992.tb00657.x

Hillman, A. J. (2005). Politicians on the board of directors: do connections affect the bottom line? Journal of Management, 31(3), 464-481. doi: 10.1177/0149206304272187

Hillman, A., \& Keim, G. (2001). Shareholder value, stakeholder management, and social issues: what's the bottom line? Strategic Management Journal, 22(2), 125-139. doi: 10.1002/10970266(200101)22:2<125::AID-SMJ150>3.0.CO;2-H

Holtbrügge, D., Berg, N., \& Puck, J. (2007). To bribe or to convince? Political stakeholders and political activities in German multinational corporations. International Business Review, 16(1), 47-67. doi: 10.1016/j.ibusrev.2006.11.001

Hoskisson, R., Eden, L., Lau, C., \& Wright, M. (2000). Strategy in emerging economies. Academy of Management Journal, 43(3), 249-267. doi: 10.2307/1556394

Istaitieh, A., \& Rodriquez-Fernandez, J. M. (2006). Factor-product markets and firm's capital structure: a literature review. Review of Financial Economics, 15(1), 49-75. doi: 10.1016/j.rfe.2005.02.001

Jensen, M. C. (2000). Value maximization, stakeholder theory, and the corporate objective function. Business Ethics Quarterly, 12(2), 235-256. doi: 10.2307/3857812

Jensen, M., \& Meckling, W. (1976). Theory of the firm: managerial behavior, agency costs and ownership structure. Journal of Finance Economics, 3(4), 305-360. doi: 10.2139/ssrn.94043

Jones, T. (1995). Instrumental stakeholder theory: a synthesis of ethics and economics. The Academy of Management Review, 20(2), 404-437. doi: 10.2307/258852

Jones, T. M., \& Wicks, A. C. (1999). Convergent stakeholder theory. Academy of Management Review, 24(2), 206-221. doi: 10.2307/259075

Key, S. (1999). Toward a new theory of the firm: a critique of stakeholder theory. Management Decision, 37(4), 317-328. doi: 10.1108/00251749910269366

Khanna, T., \& Palepu, K. (2000). The future of business groups in emerging markets: long-run evidence from Chile. Academy of Management Journal, 43(3), 268-285. doi: 10.2307/1556395

Klein, B., Crawford, R., \& Alchian, A. (1978). Vertical integration, appropriable rents, and the competitive contracting process. Journal of Law and Economics, 21(2), 297-326.

La Porta, R., Lopez-de-Silanes, F., \& Shleifer, A. (1999). Corporate ownership around the world. Journal of Finance, 54(2), 471-518. doi: 10.1111/0022-1082.00115

Luk, C., Yau, O., Tse, A., Sin, L., \& Chow, R. (2005). Stakeholder orientation and business performance: the case of service companies in China. Journal of International Marketing, 13(1), 89-110. doi: 10.1509/jimk.13.1.89.58536

Luque, M. S., Washburn, N. T., Waldman, D. A., \& House, R. J. (2008). Unrequited profit: how stakeholder and economic values relate to subordinates' perceptions of leadership and firm performance. Administrative Science Quarterly, 53(4), 626-654. doi: 10.2189/asqu.53.4.626

Macaulay, S. (1963). Non contractual relations in business. American Sociological Review, 28(1), 5570. doi: $10.2307 / 2090458$ 
MacNeil, I. (1978). Contracts: adjustments of long-term economic relations under classical, neoclassical, and relational contract law. Northwestern University Law Review, 72(6), 854-906.

MCevily, B., Perrone, V., \& Zaheer, A. (2003). Trust as an organizing principle. Organization Science, 14(1), 91-103. doi: 10.1287/orsc.14.1.91.12814

McGahan, A. M., \& Porter, M. E. (1997). How much does industry matter, really? [Special Issue]. Strategic Management Journal, 18, 15-30. doi: 10.1002/(SICI)10970266(199707)18:1+<15::AID-SMJ916>3.0.CO;2-1

McGahan, A., \& Victer, R. (2010). How much does home country matter to corporate profitability? Journal of International Business Studies, 41(1), 142-65. doi: 10.1057/jibs.2009.69

McGuire, J., Sundgren, A., \& Schneeweis, T. (1988). Corporate social responsibility and firm financial performance. Academy of Management Journal, 31(4), 854-872. doi: 10.2307/256342

McWilliams, A., Fleet, D., \& Cory, K. (2002). Raising rivals' costs through political strategy: an extension of resource-based theory. Journal of Management Studies, 39(5), 707-724. doi: $10.1111 / 1467-6486.00308$

Neville, B., \& Menguc, B. (2006). Stakeholder multiplicity: toward an understanding of the interactions between stakeholders. Journal of Business Ethics, 66(4), 377-391. doi: 10.1007/s10551-006-0015-4

Nooteboom, B. (1993). An analysis of specificity in transaction cost economics. Organization Studies, 14(3), 443-451. doi: 10.1177/017084069301400306

North, D. (1981). Structure and change in economic history. New York: Norton.

Pajumen, K. (2006). Living in agreement with a contract: the management of moral and viable firmstakeholder relationships. Journal of Business Ethics, 68(3), 243-258. doi: 10.1007/s10551-0069013-9

Parmar, B., Freeman, R. E., Harrison, J., Wicks, A. C., Purnell, L., \& Colle, S. (2010). Stakeholder theory: the state of the art. The Academy of Management Annals, 4(1), 403-445. doi: $10.1080 / 19416520.2010 .495581$

Pearce, J. (2001). Organization and management in the embrace of government. Mahwah, New Jersey: Lawrence Erlbaum Associates.

Peng, M. (2002). Towards an institution-based view of business strategy. Asia Pacific Journal of Management, 19(2-3), 251-267. doi: 10.1023/A:1016291702714

Peng, M., \& Luo, Y. (2000). Managerial ties and firm performance in a transition economy: the nature of a micro-macro link. Academy of Management Journal, 43(3), 486-501. doi: 10.2307/1556406

Phillips, R., Freeman, R., \& Wicks, A. (2003). What stakeholder theory is not. Business Ethics Quarterly, 13(4), 479-502.

Plaza-Úbeda, J., Burgos-Jiménez, J., \& Carmona-Moreno, E. (2010). Measuring stakeholder integration: knowledge, interaction and adaptational behavior dimensions. Journal of Business Ethics, 93(3), 419-442. doi: 10.1007/s10551-009-0231-9

Post, J., Preston, L. E., \& Sachs, S. (2002). Redefining the corporation: stakeholder management and organizational wealth. Stanford, CA: Stanford University Press.

Rahman, Z., \& Bhattacharyya, S. (2003). First mover advantages in emerging economies: a discussion. Management Decision, 41(2), 141-147. doi: 10.1108/00251740310457588 
Revista Exame. (2001). Guia Exame de boa cidadania corporativa (754a. ed.). São Paulo: Editora Abril.

Revista Exame. (2002). Guia Exame de boa cidadania corporativa (781a. ed.). São Paulo: Editora Abril.

Revista Exame. (2003). Guia Exame de boa cidadania corporativa (808a. ed.). São Paulo: Editora Abril.

Revista Exame. (2004). Guia Exame de boa cidadania corporativa (833a. ed.). São Paulo: Editora Abril.

Rueda-Manzanares, A., Arago'n-Correa, A., \& Sharma, S. (2008). The influence of stakeholders on the environmental strategy of service firms: the moderating effects of complexity, uncertainly and munificience. British Journal of Management, 19(2), 185-203. doi: 10.1111/j.14678551.2007.00538.x

Rumelt, R. P. (1991). How much does industry matter? Strategic Management Journal, 12(3), 167185. doi: $10.1002 / \mathrm{smj} .4250120302$

Samuels, D. (2001). Money, elections, and democracy in Brazil. Latin American Politics and Society, 43(2), 27-48. doi: 10.1111/j.1548-2456.2001.tb00398.x

Samuels, D. (2002). Pork barreling is not credit claiming or advertising: campaign finance and sources of the personal vote in Brazil. Journal of Politics, 64(3), 845-863. doi: 10.1111/00223816.00149

Sapienza, P. (2004). The effects of government ownership on bank lending. Journal of Financial Economics, 72(2), 357-384. doi: 10.1016/j.jfineco.2002.10.002

Shankman, N. A. (1999). Reframing the debate between agency and stakeholder theories of the firm. Journal of Business Ethics, 19(4), 319-334. doi: 10.1023/A:1005880031427

Smith, H. J. (2003). The shareholders vs. stakeholders debate. MIT Sloan Management Review, 44(4), $85-90$.

Tihanyi, L., \& Hegarty, W. (2007). Political interests and the emergence of commercial banking in transition economies. Journal of Management Studies, 44(5), 788-813. doi: 10.1111/j.14676486.2007.00707.x

Waddock, S., \& Graves, S. (1997). The corporate social performance-financial performance link. Strategic Management Journal, 18(4), 303-319. doi: 10.1002/(SICI)10970266(199704)18:4<303::AID-SMJ869>3.3.CO;2-7

Wan, W. (2005). Country resource environments, firm capabilities, and corporate diversification strategies. Journal of Management Studies, 42(1), 161-182. doi: 10.1111/j.14676486.2005.00492.x

Wicks, A., \& Berman, S. (2004). The effects of context on trust in firm-stakeholder relationships: the institutional environment, trust creation, and firm performance. Business Ethics Quarterly, 14(1), 141-160.

Wicks, A., Berman, S., \& Jones, T. (1999). The structure of optimal trust: moral and strategic implications. Academy of Management Review, 24(1), 99-116. doi: 10.2307/259039

Williamson, O. E. (1975). Markets and hierarchies: Analysis and antitrust implications. New York: Free Press. 
Williamson, O. (1985). The economic institutions of capitalism. New York: The Free Press.

Williamson, O., \& Winter, S. (Eds.). (1991). The Nature of the firm: origins, evolution, and development. Oxford: Oxford University Press.

Winn, M., \& Keller, L. (2001). A modeling methodology for multiobjective multistakeholder decisions: implications for research. Journal of Management Inquiry, 10(2), 166-181. doi: $10.1177 / 1056492601102020$

Wright, M., Filatotchev, I., Hoskisson, R., \& Peng, M. (2005). Strategy research in emerging economies: challenging the conventional wisdom. Journal of Management Studies, 42(1), 1-33. doi: $10.1111 /$ j.1467-6486.2005.00487.x

Yiu, D., Bruton, G., \& Lu, Y. (2005). Understanding business group performance in an emergent economy: acquiring resources and capabilities in order to prosper. Journal of Management Studies, 42(1), 183-206. doi: 10.1111/j.1467-6486.2005.00493.x 